胃に転移をきたした副鼻腔原発 malignant fibrous

\title{
histiocytoma $(\mathrm{MFH})$ の 1 例
}

\author{
札幌医科大学第 1 外科（主任：平田公一教授) \\ 木村仁伝野隆一浦英樹磯部将人 \\ 小出真二湯山友一平田公一 \\ 同耳鼻咽喉科 \\ 朝 倉 光 司
}

症例は62歳男性で, 主訴は左眼流涙. 平成 6 年 1 月頃より症状が出現したため近医受 診.CTで左副鼻腔を中心に腫癔性病変が認められ，当院耳鼻咽喉科入入院となる.篩骨 洞開放生検で MFH の診断に至る。術前化学療法として FEMP 療法施行中, 胃部不快感 の出現を見たため上部消化管内視鏡施行. 胃体部大彎に径 $40 \times 40 \mathrm{~mm}$ の隆起性病変を認 めた. Biopsy の結果, malignant fibrous histiocytoma $(\mathrm{MFH})$ と診断. ${ }^{67} \mathrm{Ga}$ scintigraphy では左副鼻腔と左上腹部（胃）に異常集積像を認めた。同脳神経外科で原発巣摘出術施 行後, 当科転科となり幽門側胃切除術を施行. 副鼻腔原発 MFH の胃転移と診断された. このような転移を示した症例は極めて稀であり，文献的考察を加えて報告する。

索引用語：悪性線維性組織球症, 副鼻腔腫瘍, 胃転移

はじめに

副鼻腔原発の悪性線維性組織球症（malignant fibrous histiocytoma : MFH) は全 MFH の約 $3 \%$ と 稀な疾患である．胃に転移することは極めて稀なこと であり，原発巣および転移病巣をともに切除しえた症 例を経験したので報告する。

$$
\text { 症例 }
$$

患者：62歳, 男性.

主訴: 左眼流涙.

家族歴：特記すへきことなし.

既往歴：特記すべきことなし。

現病歴: 平成 6 年 1 月頃より左眼流涙出現し, 近医 受診. 2 月頃より左眼突出を認めた. CT で左副鼻腔か ら眼窝に及ぶ腫瘍の存在を指摘され，3月22日当院耳 鼻咽喉科入院となり，脳神経外科の協力のもとに左眼 球摘出と脳実質の一部切除を受けた。その後化学療法 を施行したが，その過程で嘔気が出現し，上部消化管 検查の結果, 胃体部大彎側に隆起性病変を認め当科転 科となる。

耳鼻咽喉科入院時現症：左眼流涙, 左眼突出を生し
ていたが腹部腫瘤および表在りンパ節を触知しない. 心，肺に異常を認めない.

耳鼻咽喉科入院時検査所見：血液検査では，GOT, GPT の軽度上昇を認める他, 特に異常を認めない. 腫 瘍マーカーは, CEA-II 2.6ng/ml, SCC $1.3 \mathrm{ng} / \mathrm{ml}, \mathrm{IAP}$ $534 \mu \mathrm{l} / \mathrm{ml}$ といずれも正常域值にあった（表 1 ).

耳鼻咽喉科頭部 CT 所見：副鼻腔病変の進展範囲は 左眼窩を中心に笠骨洞，上顎洞，鼻腔におよび，また 眼窝底の破壊を伴う脳実質への直接浸潤を認めた（図 1 ).

\section{表 1 入院時検査所見}

\begin{tabular}{|c|c|c|c|c|c|}
\hline $\begin{array}{l}\text { RBC } \\
\text { Hb } \\
\text { Ht } \\
\text { WBC } \\
\text { PIt } \\
\text { T.bil } \\
\text { D.bil } \\
\text { GOT } \\
\text { GPT } \\
\text { ALP } \\
\text { Y-GT } \\
\text { LDH } \\
\text { ChE } \\
\text { AmY } \\
\text { CK }\end{array}$ & $\begin{array}{r}423 \\
14.5 \\
42.2 \\
4.0 \\
177 \\
0.1 \\
0.4 \\
42 \\
43 \\
202 \\
187 \\
282 \\
195 \\
174 \\
122\end{array}$ & $\begin{array}{l}\times 10^{4} / \mathrm{mm}^{3} \\
9 / \mathrm{dl} \\
\% \\
\times 10^{4} / \mathrm{mm}^{4} \\
\times 10^{3} / \mathrm{mm}^{2} \\
\mathrm{mg} / \mathrm{dl} \\
\mathrm{mg} / \mathrm{dl} \\
\mathrm{IU} / / \\
\mathrm{IU} / 1 \\
\mathrm{IU} / 1 \\
\mathrm{IU} / / \\
\mathrm{IU} / \mathrm{I} \\
\mathrm{IU} / \mathrm{I} \\
\mathrm{IU} / \mathrm{I} \\
\mathrm{IU} / \mathrm{I}\end{array}$ & $\begin{array}{l}\text { TP } \\
\text { Alb } \\
\mathrm{Na} \\
\mathrm{K} \\
\mathrm{Cl} \\
\mathrm{Cre} \\
\text { UA } \\
\mathrm{Ca} \\
\text { BUN } \\
\text { Tumor } \\
\text { CEA-II } \\
\text { SCC } \\
\text { IAP }\end{array}$ & $\begin{array}{c}6.7 \\
4.1 \\
143 \\
3.9 \\
109 \\
1.1 \\
6.1 \\
8.5 \\
12 \\
\text { marker } \\
2.6 \\
1.3 \\
534\end{array}$ & $\begin{array}{l}\mathrm{g} / \mathrm{dl} \\
\mathrm{g} / \mathrm{dl} \\
\mathrm{mEq} / \mathrm{l} \\
\mathrm{mEq} / \mathrm{I} \\
\mathrm{mEq} / \mathrm{l} \\
\mathrm{mEq} / \mathrm{I} \\
\mathrm{mg} / \mathrm{dl} \\
\mathrm{mg} / \mathrm{dl} \\
\mathrm{mg} / \mathrm{dl}\end{array}$ \\
\hline
\end{tabular}

1996年 6月19日受付 1996年11月15日採用 
胃 $\mathbf{X}$ 線検査所見：腹臥位充影像では，胃体部大彎側 に上部消化管内視鏡所見と一致する径 $40 \times 40 \mathrm{~mm}$ 大の 隆起性病変を認めた。二重造影像では, 腫瘍の進展範 囲は隆起を示した病巣部よりさらに広いと考えられ た. 胃壁の伸展性は良好であるものの, 粘膜下での浸 潤増殖が疑われた (図 2 ).

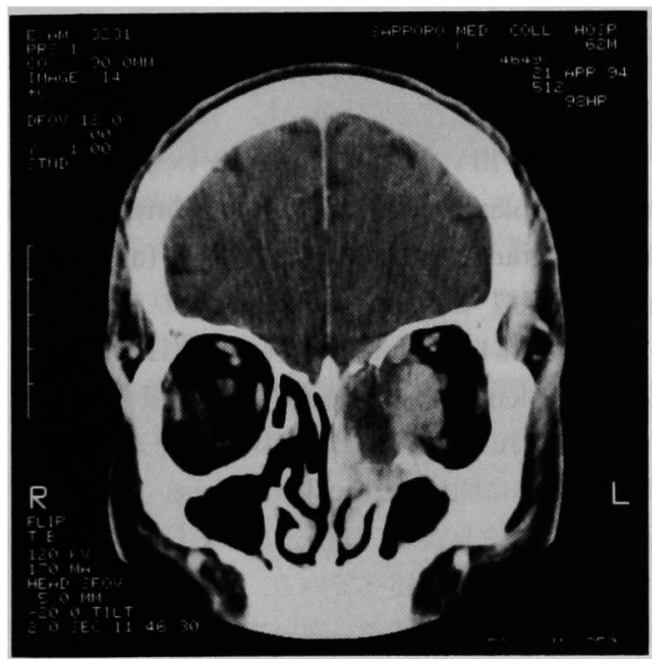

図 1 頭部 CT 検査 : 左眼窩を中心に脳実質への直接 漫潤を認める。
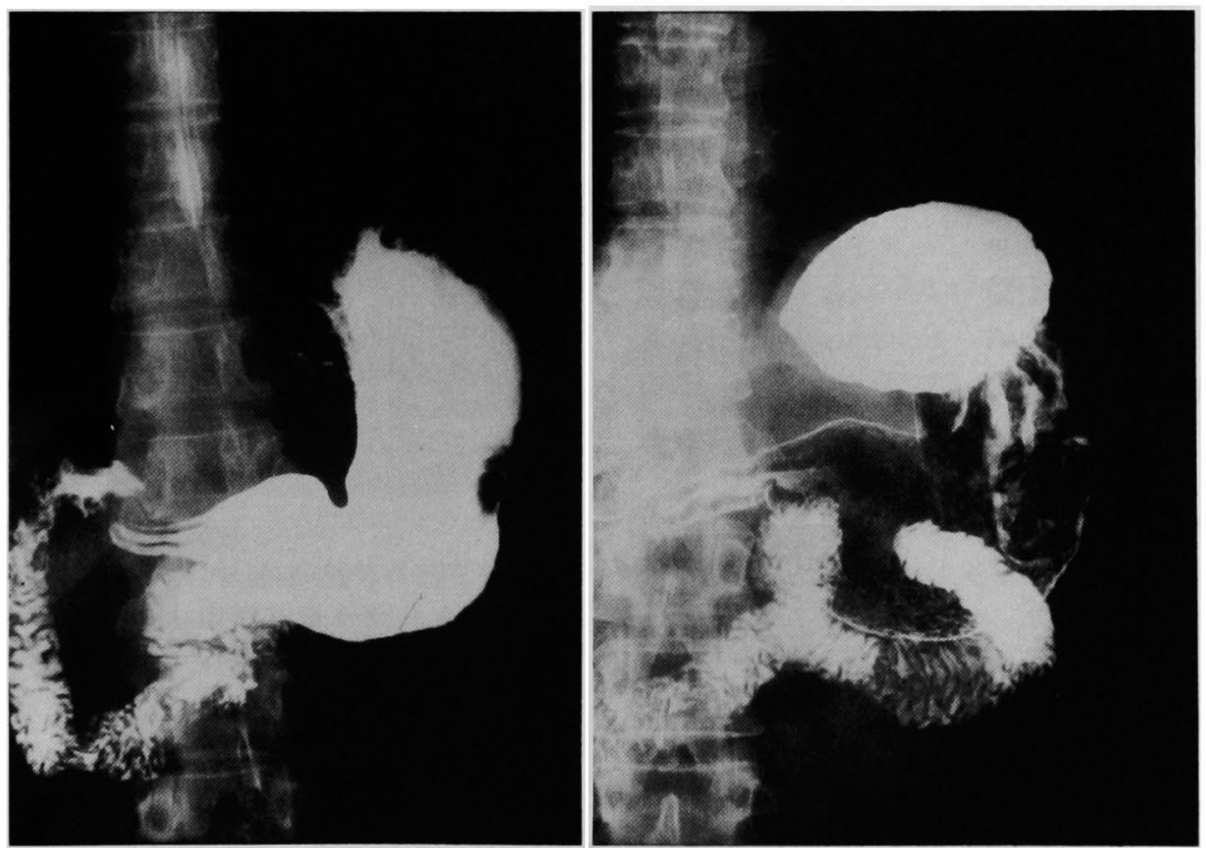

図 2 胃 $\mathbf{X}$ 線検査：腹臥位充影像 (左) では胃体部大彎側に径 $4 \mathrm{~cm}$ の隆起性病変を認 めた. 二重像影像（右）ではさらに広い粘膜下病変を認めた。 


\section{考 察}

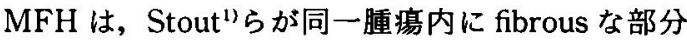
と histiocytic な部分を持つ軟部腫瘍と定義したこと

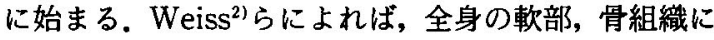
生じ, 肉腫の中では最も頻度が高く, 発生部位別頻度

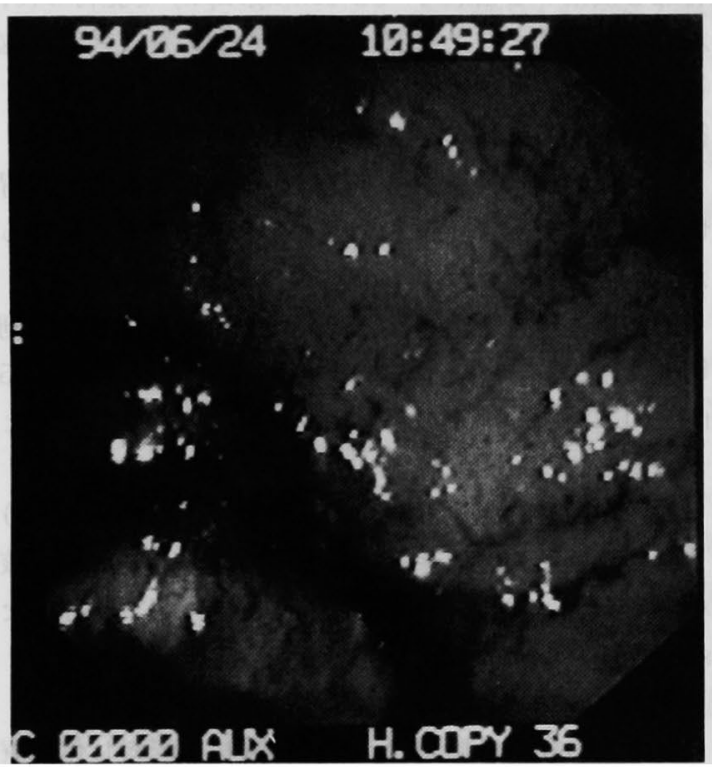

図 3 胃内視鏡検查：胃体部大彎側に粘膜の発赤を 伴った径 $4 \mathrm{~cm}$ の隆起性病変を認めた。
ては四肢 (68\%)，後腹膜および腹腔 $(16 \%)$, 躯幹

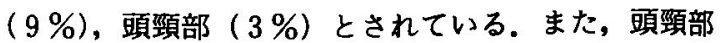
の MFH のなかで頻度が高いのは副鼻腔である344!

性別でると, 頭頸部の MFH は 4：1で男性に多 い5．年齢は全体の MFH では50〜70歳の高齢者に多

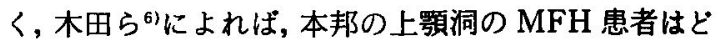
の年跉層にも発生するが30歳〜60歳代に多いと報告し ている。

病理組織学的には, 非常に多彩で多型細胞腫の一つ と考えられている。病理分類としては, Enziger, Weiss らかの分類が用いられており，多い順に，通常型 (storiform-plemorphic type), 粘液型 (myxoid type), 巨細胞型 (giant cell type), 類血管腫型 (angiomatoid type)，炎症型 (inflammatory type) の 5 種類に分類 される.本邦における上㯋洞の $\mathrm{MFH} の$ 組織型は storiform-plemorphic type が75.5\%と最も多い6). 今 回のわれわれの症例もこの病理型に分類された。 MFH の転移に関して, Enziger, Weiss ら ${ }^{3}$ は, 通常 2 年以内に転移をきたし, 転移先としては肺,リンパ節, 肝, 骨の順に多いと述べている. 本邦報告例で最も多 い転移様式は全身転移で, 次いでリンパ節, 肝, 肺の 順であった ${ }^{6)}$. 本症例の様な頭頸部原発 MFH の胃へ の転移を認めた例は，本邦で文献上検索し得た範囲で は 1 例のみであった”゙.

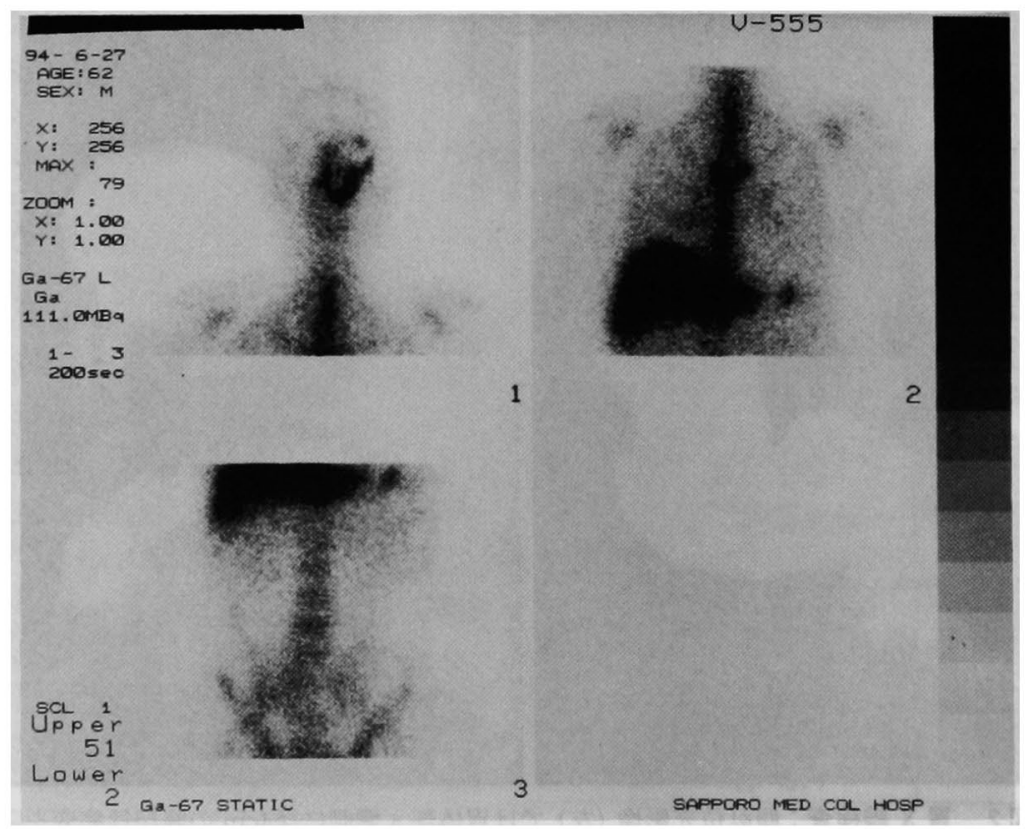

图 $4{ }^{67} \mathrm{Ga}$ scintigraphy : 左副鼻腔周辺と左上腹部（胃）に異常集積像を認めた. 


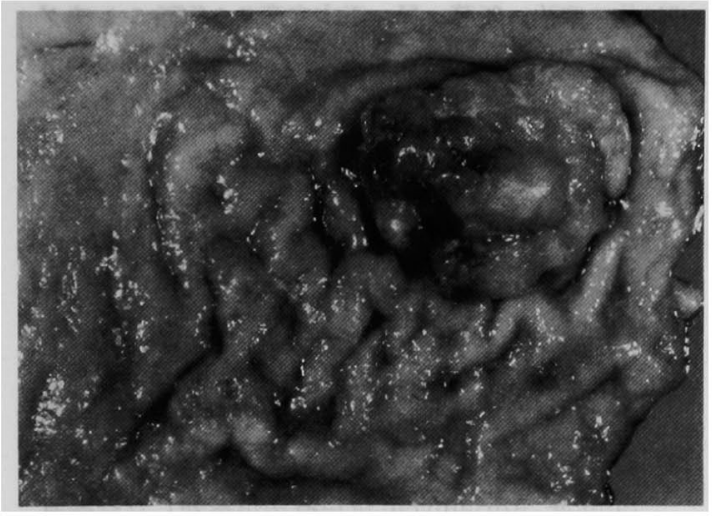

图 5 摘出標本：小唄側切開標本. 胃体部大彎側に径 $4.5 \times 4.0 \mathrm{~cm}$ と径 $1.5 \times 1.5 \mathrm{~cm}$ の粘膜下腫瘍を認め た.

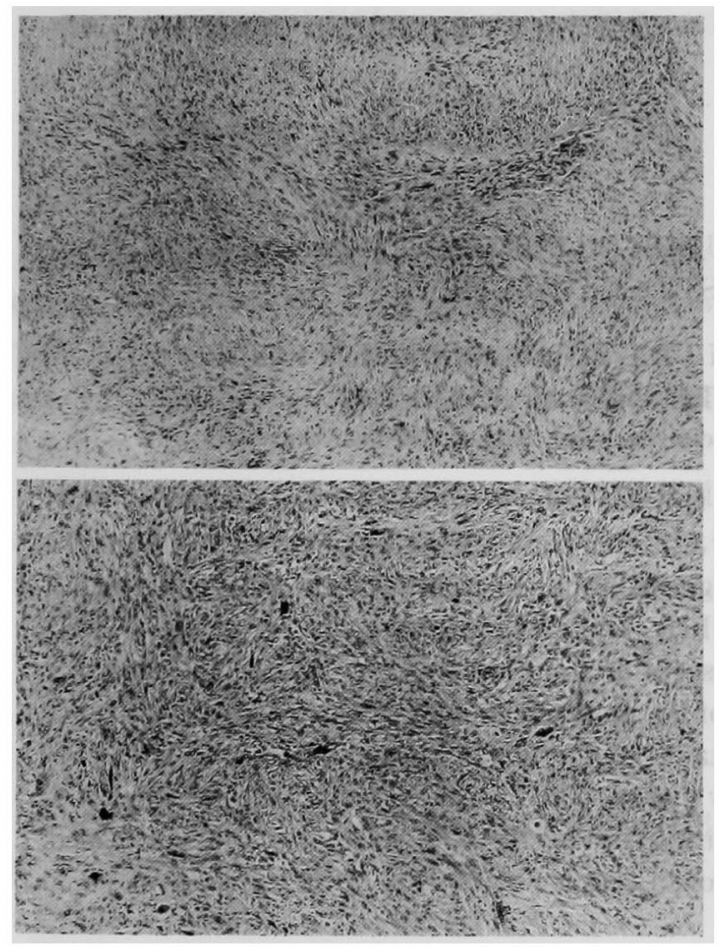

図 6A．副臭腔原発采組織標本

図 6B 胃転移柴組織標本：紡錘型の線維芽細胞と類 円形ないし棈円形の組織球様細胞からなる storiform-plemolphic type の MFH と診断された (HE 染色 $\times 40)$.

$$
\frac{\mathrm{A}}{\mathrm{B}}
$$

高田ら ${ }^{8)}$ や住ら 巣の検索, 経過観察や治療効果の判定に有効であると
報告しており，本症例でも原発巣（左副鼻腔周辺）と 左上腹部 (胃) への転移巣に異常集積像を認めた.

$\mathrm{MFH}$ の治療は従来より手術による腫瘍全摘出が基 本である，MFH は肉眼的腫瘍境界よりさらに腫瘍が 広がっていることが多く，広範囲に切除することが重 要である. 本症例でも, 左眼球摘出と脳実質の一部切 除を伴う原発巣切除術が施行された. しかし, 頭頸部 の MFH の場合, 解剖学的に全切除は難しいことが多 い. 胃転移巣に対しては幽門側胃切除術を施行し, 再 建は Billroth-I 法で行った。

放射線療法は術後局所制御の補助療法として用いら れることがあるが，その有効性は低いと考えられてい る6).

化学療法については様々な薬剤が試みられているが 有効性は極めて低い.Bacci ら ${ }^{10}$ は MFHに対する adjuvant あるいは neo-adjuvant を施行した化学療法群 と手術単独群の予後を比較した結果, 手術単独群より 化学療法を併用した方が明らかに予後が良いと報告し ている. 本症例では術前多剤併用化学療法として富永 $ら^{11)}$ の FEMP 療法 (F : Vindesin Img, E : Cyclophosphamide 50mg, M: 6-MP 50mg, P: Prednisolone $30 \mathrm{mg}$ )に従い 2 クール施行した。 また, 耳鼻咽喉科転 科後, 藤田ら ${ }^{12)}$ (CDDP : Cisplatin 30mg, IFX : Ifosfamide 2,250mg, ADM : Adriamycin $45 \mathrm{mg}$ ) を

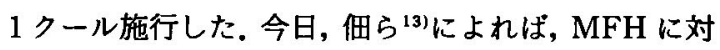
する免疫賦活剂の使用の可能性を示唆しており, 今後 期待が持たれている.

副鼻腔原発の MFH の予後は他部位と比べて悪い と報告されている. 本邦の上額洞の $\mathrm{MFH} の 5$ 年生存 率は $23 \%$ と極めて悪い6). 組織型による予後の差異は angiomatoid type および myxoid type が最も予後が よく, inflammatory type おょび storiformplemorphic type は中間で, giant cell type が最も予 後が悪いという報告がある4).

$$
\text { まとめ }
$$

今回われわれは, 副畺腔原発 MFH の胃転移を伴う 非常に稀な症例を経験しそれを切除しえたので若干の 文献的考察を加え報告した。

\section{文献}

1) Stout AP, Latters $R$ : Tumors of the soft tissues, Fascicle 1, In Atlas of Tumor Pathology, 2nd ser, Washington, DC, Armed Forces Institute of Pathology, 1967

2) Weiss SW, Enzinger FM: Malignant fibrous 
histiocytoma : An analysis of 200 cases. Cancer $41: 2250-2266,1978$

3) Enzinger FM, Weiss SW : Malignant fibrohistiocytic tumors. Soft Tissue Tumors. CV Mosvy Co, St Louis, 1983, pl60- 198

4) Barnes L, Kanbour A: Malignant fibrous histiocytoma of the head and neck ; a report of 12 cases. Arch Otolaryngo Head Neck Surg 114 : 1149-1156, 1988

5) Biltzer A, Lawson W, Biller HE: Malignant fibrous histiocytoma of the head and neck. Laryngoscope $87:$ 1479-1499, 1977

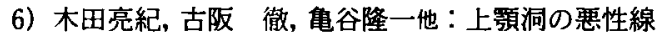
維組織球症例。耳鼻臨 $83: 577-587,1990$

7) Sonobe H, Taguchi K, Motoi M, et al: Malig. nant fibrous histiocytoma of maxillary sinus. Acta Pathol Jpn $30: 79-89,1980$

8）高田政彦, 坂本 力, 青木 茂他：悪性線維性組織 球腫の画像診断. 臨画像 $3: 94-99,1987$
9）住 幸治, 新藤 昇, 玉本文彦他: ${ }^{67} \mathrm{Ga}$ シンチグ ラフィが経過観察に有用であった Malignant fibrous histiocytoma $の 1$ 例. 臨核医 20:8589,1987

10) Bacci G, Splingfield D, Capanna R, et al: Adjuvant chemotherapy for malignant fibrous histiocytoma in the femur and tibia. $J$ Bone Joint Surg $67: 620-625,1985$

11）富永 健, 朴沢二郎, 斎藤久樹他：㽡副鼻腔悪性線 維性組織球症の 2 症例. 耳勫臨 $83: 49-56,1990$

12）藤田昭久, 井斎偉矢, 近藤正道他: Cisplatin, Ifosfamide, Adriamycin 併用療法が奏効した空腸原 発 Malignant Fibrous Histiocytoma（MFH）の 1 例. 癌と化療 $20: 2053-2056,1993$

13）佃守, 久保田彰, 新井泰弘他：Malignant fibrous histiocytoma 樹立細胞の制癌用および免 疫担当細胞に対する感受性. 耳鼻臨 95：207一 213,1992

\title{
A CASE OF METASTATIC GASTRIC TUMOR OF PRIMARY PARANASAL MALIGNANT FIBROUS HISTIOCYTOMA (MFH)
}

\author{
Hitoshi KIMURA, Ryuichi DENNO, Hideki URA, Masato ISOBE, Sinji KOIDE, \\ Yuichi YUYAMA, Kouichi HIRATA and Kouji ASAKURA*, \\ First Department of Surgery and Department of Otolalyngology*, Sapporo Medical University
}

A 62-year-old man was referred to the hospital for tears of the left eye lasting since January, 1994 . A tumor in the left paranasal cavity was revealed by CT, therefore the patient was admitted to the department of otolaryngology in our hospital. The diagnosis obtained from an open biopsy of the left ethomoid sinus was malignant fibrous histiocytoma (MFH). While neo-adjuvant chemotherapy (FEMP) was done, GTF was performed for upper abdominal discomforts and we found a $4 \mathrm{~cm}$-sized tubercular lesion at the side of the greater curvature of the body of the stomach. The diagnosis of MFH was made by a biopsy. ${ }^{67} \mathrm{Ga}$ scintigraphy visualized abnormal uptakes at the left paranasal cavity and left upper abdomen (stomach). After a resection of the primary tumor was carried out at the dapartment of neurosurgery, he changed to the first department of surgery and a distal gastrectomy was performed. There has been only one case of metastatic gastric tumor of primary paranasal MFH as far as we could search in the Japanese literature. 